\title{
The Adaptive Reuse of Kirkuk Citadel
}

\section{Mustafa Mokhtar* Mustafa Korumaz ${ }^{* *}$}

Keywords: Adaptive reuse, büyüg ev, kirkuk citadel.

*Master.Student, Selcuk University, Departement of Architecture, KONYA E-mail: small_world73@yahoo.com Orcid ID: http://orcid.org/0000-0002-98813784

**Assistant Professor, Selcuk University, Departement of Architecture, KONYA E-mail: mkorumaz@selcuk.edu.tr Orcid ID: http://orcid.org/0000-0001-63379087

Evolution of the built environments bridges past and present to the future and embrace memory. However the cities as organisms are in a dilemma along with the loss of city memories and city spirits. These collective memories that bring spirits to a place play very important role and determine the cultural significance of places. The main contribution of this study is to emphasize the importance of adaptive reuse as a carrier of spirits to have a collective memory in order to sustain the 
development of a place. This article explores the relations between spirit and memory of a place by focusing of adaptive reuse project in Kirkuk citadel. Aim of this study is to question and evaluate restoration of Kirkuk Citadel in terms of urban identity and sense of place referring the early Kirkuk city and development of it. This paper also intends to put important guidelines for the future restoration projects of Kirkuk citadel - which is very urgently required - and high lights the importance of revitalizing this area, which is now the semi-dead heart of the city. The paper advocates policy makers is to increase the adaptive reuse policy as an integral tool of regeneration and sustainability policies in order not to lose collective memory.

\section{INTRODUCTION}

In contemporary conservation theory and practise, adaptive reuse is considered an important strategy towards conservation of cultural heritage (Machado, 1976, Jessen \& Schneider 2003). The term 'adaptive reuse' - also called 'remodelling', 'retrofitting', 'conversion', 'adaptation', 'reworking', 'rehabilitation' or 'refurbishment' (Giebeler, G. 2009) and repurposing. Adaptive reuse vocabulary means "The renovation and reuse of preexisting structures for new purposes" (Merriam Webster Dictionary). The process of converting a building to a use other than that for which it was designed, e.g., changing a factory into housing. Such conversion accomplished with varying alterations to the building.

The historical buildings of a city represents the time line in which the city developed during the history, they give the city its distinctive identity, there existance across the time gives familiarity to the place, they are combined with common memory of the citizens. Conserving these buildings is not only a moral issu now, but enviremental, economic and social too, they are priceless once we loose them, we loose them for ever, it cant be replaced, even if we dublicate it, we never get the same feeling again.

Kirkuk City for thousands years was the Citadel of Kirkuk, and then the settlments spread around the Citadel and the urban fabric grow bigger. When the modern homes were built people started to leave the Citadel, building new and bigger houses, the infrastrucre of the Citadel was neglected and the heart of city turned into slums, sometimes the negligence was intended politicaly to change the city demographly by moving the Turkmen ethnicity from the old city and then eracing their heritage, this was unfortunatly occured during Saddam's regime during the ninetees of the past century, after evacuating the people of the Citadel, in purpose that been said was a restoration project of the citadel. Then it was clear to be the opposite by all meanings, among more than 650 traditional houses, only 45 was remained (Saatçi, 2003). 
Beside all that the advances in technology and commerce, including the growth of industrial and office automation, and user demands for more comfortable environments for work and leisure have led to large number of buildings becoming obsolete or redundant and these changes have provided an abundance of buildings suitable for rehabilitation and reuse (Johnson 1996). The new architecture in Kirkuk separated from the history and heritage of the city, people were fascinating by the modern architecture. Contemperory architecture states that we should not live in a bright shining new future, anymore than we should hide in a comfortable pastiche of the past. We must inhabit an ever-evolving present, motivated by the possibilities of change, restricted by the baggage of memoryand experience (Chipperfield, 1997). The issue is no longer about the new versus old, but about the nature of the vital relationship between the two. The new architecture is about process rather than product. It welcomes the dynamic of the future and addresses the lessons of the past (Powell, 1999). The Citadel represent's the heart and the center of the City of Kirkuk, despite being in this importance its antiquated and abandoned for decay, Its really hard to imagine city center with area more than $200,000 \mathrm{~m}^{2}$ and nearly with no significant use for it, in order to revitilize this area adaptive reuse was suggested as the main policy. Bringing various uses to the old urban fabric and creating exciting spaces in what Latham describes as creative reuse (Latham, 2000).

\section{GENERAL EXAMINATION OF ADAPTIVE REUSE}

\section{Adaptive Reuse Stratigies}

According to a littreture review in PHL University College \& Hasselt University, Belgium, they identified three different littreture approaches in the field of heritage conservation and architecture: typological, technical and architectural strategies (Plevoets \& Cleempoel). In typological approach Cantacuzino organised the historical buildings according to their building type before conversion (Cantacuzino, 1989). According to this approach religeous buildings can convert into different use but in the same catgory of relireous buildings, a castle or a town house can convert to contemperory residential buildings and a craft shop or exchange can use as a modern commercial building (Cantacuzino, 1989) (Latham, 2000). in technical appraoch Highfield discusses the improvement of fire resistance, thermal performance, acoustic performance, prevention of damp penetration, condensation and timber decay (Highfield,1987). he approach's the host space merely as a shell or contai-ner and therefore give little attention to the conservation and heritage aspects. Plevoets \& Van Cleempoel in their paper presented four 
categories in strategic approach according to four books, by different architects (Plevoets \& Cleempoel). Robert, P. gives examples from ancient times up to the postmodern era (Robert, 1989). Brooker and Stone looked at exem-plary cases of contemporary conversions, for them the most important and meaningful factor in adaptive reuse is the original building (Brooker \& Stone, 2004). Jäger classification is according to the applied strategy towards the existing fabric, The cases are selected based on their architectural quality and originality (Jäger, 2010). Cramer and Breitling make a distinction between 'design strategies' and 'architectonic expressions' where by they describe design strategies as physical interventions and alterations to the building and architectonic expressions as the aesthetic qualities of the intervention (Cramer \& Breitling, 2007). These different catgories and overlapping between them are illustrated in the bellow (figure 1).

Figure 1. analogy between described stratigies (Plevoets \& Clee-mpoel, 2011)

\begin{tabular}{|c|c|c|c|c|}
\hline \multicolumn{4}{|c|}{ Design Strategies } & $\begin{array}{l}\text { Architectonic } \\
\text { Expressions }\end{array}$ \\
\hline Robert 1989 & $\begin{array}{l}\text { Brooker \& } \\
\text { Stone } 2004\end{array}$ & Jäger 2010 & \multicolumn{2}{|c|}{ Cramer \& Breitling 2007} \\
\hline Building within & Insertion & Transformation & Modernisation & Correspondence \\
\hline Building over & & & \multirow{5}{*}{ Adaptation } & \\
\hline $\begin{array}{l}\text { Building } \\
\text { around }\end{array}$ & \multirow{3}{*}{ Intervention } & Addition & & \\
\hline $\begin{array}{l}\text { Building } \\
\text { alongside }\end{array}$ & & & & - IIII) \\
\hline \multirow{2}{*}{$\begin{array}{l}\text { Adapting to a } \\
\text { new function }\end{array}$} & & Conversion & & \\
\hline & Installation & & & $\begin{array}{l}\text { Junction and } \\
\text { delineation }\end{array}$ \\
\hline $\begin{array}{l}\text { Building in the } \\
\text { style of }\end{array}$ & & & Replacement & \\
\hline $\begin{array}{l}\text { Recycling } \\
\text { materials of } \\
\text { vestiges }\end{array}$ & & & $\begin{array}{l}\text { Corrective } \\
\text { maintenance }\end{array}$ & \\
\hline
\end{tabular}

The function is the most obvious change, but other alterations may be made to the building itself such as the circulation route, the orientation, the relationship between spaces, additions may be built and other areas may be demolished' (Brooker \& Stone, 2004) It is essential that any building being considered for major refurbishment have a thorough survey undertaken to confirm its structural and constructional quality, and its compliance with building ordinances (Langston, 2008).

To make the process of adaptive reuse easier, there should be numerous strategic steps from different members of the society. A great example for succesful adaptive reuse policy is the city of Los Angeles, through innovative public policy and creative private development, Los Angeles is demonstrating how older buildings can be repurposed to serve the new, for policy leaders, they must remove regulatory barriers to make building reuse easier, using 
downtown as a policy innovator to test new ways to encourage building reuse, including the reuse of existing structures, alongside strategic infill construction and even changing parking policy. As for property owners and developers they must to conserve the original character of existing buildings, including architectural features and building materials that tell a unique story to prospective tenants and buyers, they have also to plan for diverse uses and frequent changes in use when investing in new building infrastructure and services, including elevators; heating, ventilation, and air-conditioning systems; soundproofing; and building access and design flexible interior spaces that appeal to the growing market for open plan living and work environments. They should create diverse, mixed-use urban neighborhoods that attract and support building reuse projects (Lindberg \& Goldberg, 2013).

\section{Adaptive Reuse Towards Sustainablity}

Adaptive reuse and sustainable design have a significant role in the future of architecture (Snyder, 2005). One of the important advantages of refurbishment is time, converting an existing building is faster than constructing it, rehabilitation typically takes half to three-quarters of the time necessary to demolish and reconstruct the same floor area (Johnson 1996), the shorter time lead's to fewer financial and less disruption. Despite the time advantages, the cost of converting a building is generally less than new construction because many of the building elements already exist (Langston, 2008).

From enviremental aspect using the existing stock reduces the use of new materials and the environmental impacts and $\mathrm{CO} 2$ emissions connected to their production, while the embodied energy of the existing material is preserved and not wasted. Further-more the substantial wastage from demolition that would otherwise go to landfill is also avoided (Orbasli, 2009). Energy consumption is inversely propotional with envirenment well being, a study of the wide portfolio of buildings held by the Ministry of Justice estate has revealed that pre-1900 buildings use the least energy and less energy even than buildings built between 1990 and 2000 (Wallsgrove, 2008). Therefore the UNEP emphasizes that adapting and retrofitting of existing buildings to the optimal energy efficiency standard must be given more focus by the building sector (UNEP, 2009).

\section{Architectural Conservation}

Architectural conservation is the process by which individuals or groups attempt to protect valued buildings from unwanted change (Griffith, 2010). 
Department of the Interior of United States defined the following treatment For architectural conservation, first Preservation, it is defined as the act or process of applying measures necessary to sustain the existing form, integrity, and materials of an historic property. Then there is the Rehabilitation, which is defined as the act or process of making possible a compatible use for a property through repair, alterations, and additions while preserving those portions or features which convey its historical, cultural, or architectural values. The act or process of accurately depicting the form, features, and character of a property as it appeared at a particular period of time by means of the removal of features from other periods in its history and reconstruction of missing features from the restoration period is called Restoration. Finally Reconstruction is defined as the act or process of depicting, by means of new construction, the form, features, and detailing of a non-surviving site, landscape, building, structure, or object for the purpose of replicating its appearance at a specific period of time and in its historic location (Weeks and Grimmer, 1995).

\section{Urban Identity and Sense of Place}

"If you don't know where you're from, you'll have a hard time saying where you're going." (Berry, 2014). Sense of place is a combination of characteristics that makes a place special and unique. Sense of place involves the human experience in a landscape, the local knowledge and folklore. Sense of place also grows from identifying oneself in relation to a particular piece of land on the surface of planet Earth. İt results gradually and unconsciously from inhabiting a landscape over time, becoming familiar with its physical properties, accruing history within its confines (Rydon, 2014). when live in a place especialy from childhood, you will preffer the charecters of that place in future. Environmental psychologists have quantified links between exposure to natural environments in childhood and environmental preferences later in life (Bixler, Floyd, Hammitt, 2002).

Adaptive reuse develops the urban fabric while keeping the sense of familiarity and the culture of the place, it has moral, economical and even sustainable value. Good urban revitalisation not only involves diversifying economic activities but also harnessing the heritage value and preservation of the social fabric. Every building has its own biography. A knowledge of the whole life of a building brings an essential understanding of its features and its problems (Encyclopedia, 2010). 


\section{UNIVERSAL AND LOCAL EXAMPLES}

\section{European House of photography}

The former hotel Henault de Cantobre in Marais at Paris, France was a problem building before the adaptive reuse of it. This hotel and many other hotels from seventeenth and eighteenth century in Marais, was in exhausted and threatened situation, their salvation was to bring a new cultural uses to it. The eighteenth century hotel Henault de Cantobre is a protected monument; it is prohibited to make any significant changes to its structure or appearance. However a derelict building that blocked out the views of the hotel was demolished and replaced with a new building, because the extension was a necessity. Construction began in March 1993 by Yves Lion Architecte, the work with protected monument was limited to restoration in accordance with the Batiments de France. However, a new building was attached to the rear wing of the old one. The new added building submits and undergo with its historic neighbor. A similar stone to that of the hotel used as a facing material binds the two structures together with harmony, while the insertion of vertical sheer glazing helps to avoid a sudden join between the two buildings. Old and new must cohabit; the best of new work increases the statue of the old, but without condescension says Lion. The building converted to a cultural institute (house of photography) with new uses like lecture rooms, galleries, staff rooms, library, bookshop and etc. The project attempted to retain a sense of familiarity and comfort (Powell, 1999).

A note of disagreement came from the critic Jean-Paul Robert, who argued that the old hotels should be lived in again not sold out to the culture industry.

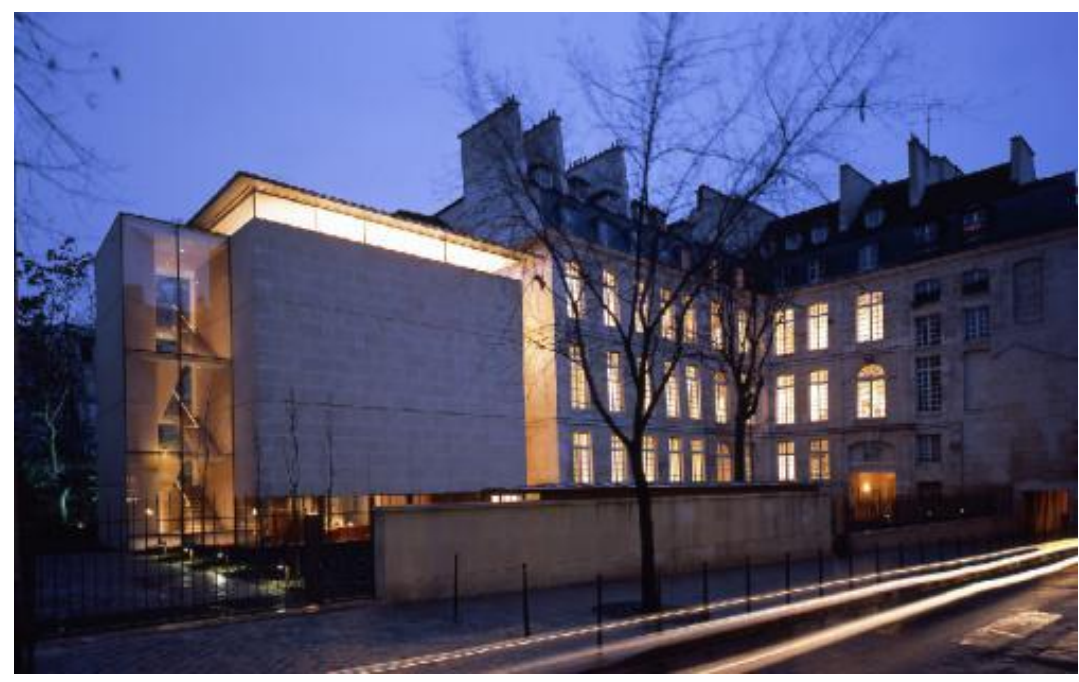

Figure 2. View of the original and added part of the house of photography building 


\section{Manouchehri House}

Manouchehri House is a boutique hotel and textile centre, originaly a 19th century merchant home in the historic quarter of Kashan, Iran. Its primary architecture dates back to the Safavid dynasty. Manouchehri House was partly ruined by the 1778 earthquake and was rebuilt in the Qajar era. In 2007, the house was bought and registered as a heritage monument, despite being in a state of disrepair (Manouchehri House, web). The initial purpose that informed the undertaking was threefold: the revival of historically significant hand-woven textile traditions of Kashan which were on the brink of extinction; the renovation, restoration and revitalisation of a historic house and its surrounding neighbourhood in order to draw attention to the vast treasury of this architectural heritage in danger; and raising awareness of the cultural, artistic and technological traditions embedded in the Islamic architectural traditions of this region. After major restoration work, It was awarded Aga Khan Award for Architecture 2014-2016 Cycle and Lonely Planet Top Choice award in 2012. This private residence has been brought back to life with the highest standards of historic preservation and the latest in modern amenities. Eight private guest rooms with unique architectural details surround a peaceful courtyard that features a reflecting pool flanked by gardens bearing local fruit. Guests are welcomed with a refreshment in the elegant lobby outfitted with traditional Iranian furnishings and showcasing an art gallery in the atrium above. A state-of-the-art subterranean movie theatre, converted from the original basement cistern. A spacious textile workshop featuring looms for velvet and brocade weaving support the revival of traditional arts of the region. These rare and precious textiles are available for purchase in the hotel's gift shop, which presents a multitude of objects from Iranian artisans and craftsmen. The project has met with so much success that it has drawn thousands of people from across the world, and has triggered many similar initiatives across the city (Aga Khan, 2014).

Figure 3. from the left view of Manouchehri house before and after renovation, and from the right the revival of historically significant hand-woven textile traditions of Kashan which were on the brink of extinction, and bellow it one of the bedrooms (Al-Jameel et. aetl, 2015).

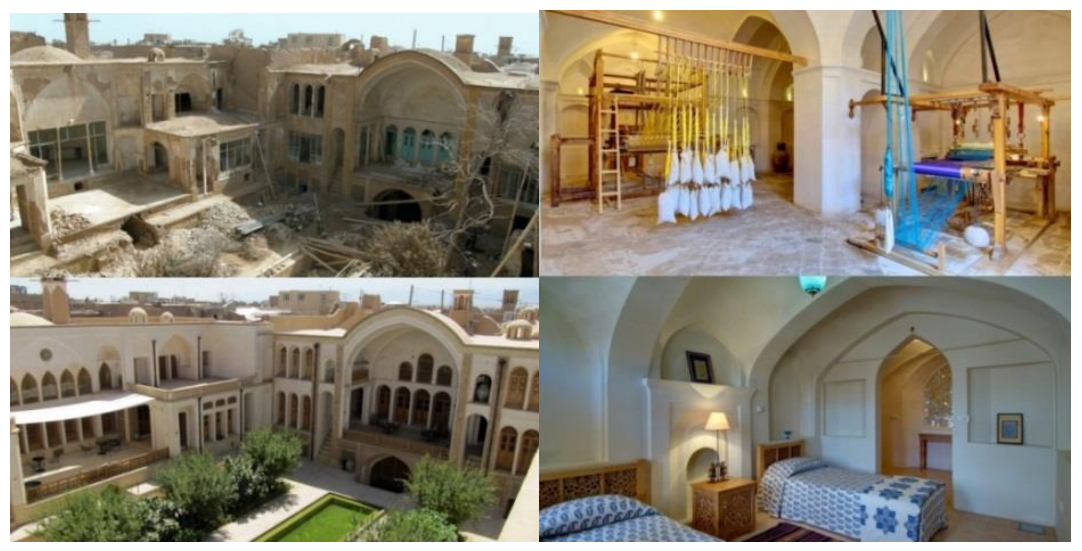




\section{Erbil Citadel Revitalization}

It is a tell or occupied mound, and the historical city center of Erbil which is recently the capital of Region of Iraq. The citadel has been inscribed on the World Heritage List since 21 June 2014. From prehistory and the Assyrian period $2300 \mathrm{BC}$, to the Sassanids, till the resent days where Turkmen citizens from Begteginids, atabeg dynesties, are occupied in this citadel for nearly a thousand years ago, to the modern day (Sourdel, 2010) where it has been claimed that the site is the oldest continuously inhabited town in the world (Unesco, 2010). Erbil Citadel has witnessed continuous deterioration from the beginning of the 20th century; the services where hard to provide, the cars where unaccessible because of narrow insanitary alleyways, with the increased impression of being old-fashioned and inconvenient have led to the departure of wealthy prominent families of the Citadel in favor of the lower city, leaving the abandoned houses to be occupied by the refugees and squatters. In 2006 Regional Government decided to depopulate the Citadel so that it could be conserved and revitalized. In 2007, Erbil Citadel Revitalization project was started by the High Commission for Erbil Citadel Revitalization (HCECR, 2016) in collaboration with UNESCO. The revitalization of Erbil Citadel is approached through the concept of adaptive reuse as the core strategy for a culturally-driven revitalization (HCECR, 2012). Adaptive reuse of Erbil Citadel has concentrated largely on the issue of the allocation of new uses for each individual building and the Citadel as a whole. İn this project it is stated that, to guide the determination of the new use for each building, the new use ought to be convenient with the spirit of the original use; the character and value of the building; the technical and practical appropriateness of the building in terms of space available, adaptability, location and the access to vehicles; and finally, the socio-economic context and the sustainability of its management framework. For the Citadel as a whole, it is stated that, the new uses allocation is inspired by the Citadel historical district division as Saray District was devoted to a predominant cultural-related use, Takya District was devoted to a predominant touristic-related use, Takya District center was devoted to a predominant office- and archeological-related use and Topkhana District was devoted to a predominant residential-related use ( $\mathrm{Al}$ Jameel, 2015). 
Figure 4. Erbil Citadel Land Use Plan Proposal (Al-Jameel, 2015)

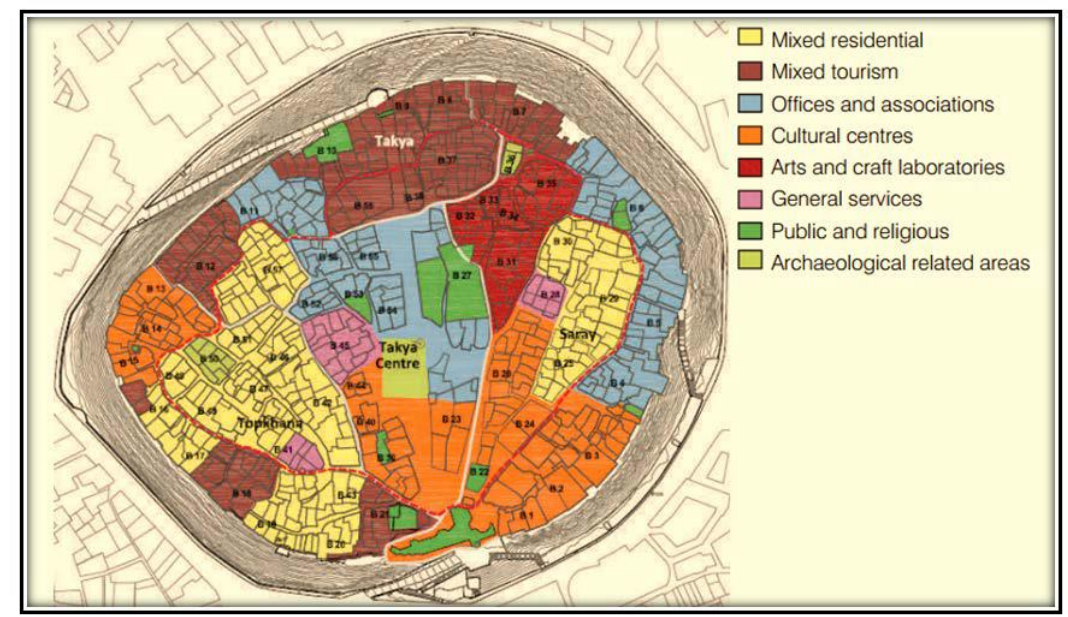

\section{HISTORICAL ASPECT OF KIRKUK CITADEL}

\section{Kirkuk Early History}

Many tablets and other remnants were found in the city dated to $2600 \mathrm{BC}$ and linked to the civilization of Sumer (Bakır-Sefer, 1965), then the Akads reigned for two centuries in this region which was known as Arrapha 2350 - 2154 BC (Edwards, Bury, Charlesworth, 1970) After two short periods - the Gutians (60 years) and the third Ur dynasty (65 years) (East, 1961) The Assyrian empire (old, middle and new) reigns over 1400 years in the region 2025 - 612 BC (Pollard, 2015). Civil wars led the Assyrian empire to disintegrate, paving the way for the Med and the new Babylonian empire to dominate the region for a short period of time (66 years). The region after $546 \mathrm{BC}$ witnessed the ages of the Persian empires, between 546 - 331 BC it was under the dominion of the Achaemenid empire and was known as Athura (or Assyria) (Sicker, 2000). The ages of the Persian empires experienced an interruption between the periods of Macedonian (332-312 BC) and Seleucids (311-150 BC) until the time of the Parthian empire. In $139 \mathrm{BC}$ along with its region the city was under the Parthian rule, till the 226 AD the Sassanid's took control of region (Samarrai, 1988). After Al-Qadisiyyah battle with the Sassanid Empire 636 AD the Islamic army entered into the city of Kirkuk (Samarrai, 1988). It remained within the boundaries of Abbasid State, which was founded in 750 BC; the origins of Kirkuk's Turkish population can be extended to this age (Saatchi, 2003). A descendant of Turkish origin mother Caliph alMu'tasim (833-842) and the son of the famous Abbasid Caliph Harun al-Rashid established a special military force from the Turks (William, 1922). In order to rescue Baghdad from the pressures of the Buyid dynasty, Abbasid Caliphs insistently invited Tuğrul Bey's army, which eventually ended the rule of the Buyids 1055 AD (Turan, 1965). With the Seljuk's dominion the period of Turkish sovereignty begins in the region (Saatçi, 2003). 
After Imad ad-Din Zengi became the "atabeg" of Mosul in 1127 (Ayalon, 1999) the region enters the sovereignty of the Zengid dynasty and then shares the sovereignty with the Ayyubids in the region. During 1258 AD the region is conquered by the Mongolian invasion; and the Ilkhanate and the Jalayirid Sultanate sequentially dominated the region. In 1411 it's noticed that Mosul and Kirkuk will entered into the Kara Koyunlu rule, also called Black Sheep Turkomans (Jawad, 1947). In 1470 the Ak Koyunlu which they were Oghuz Turkic became dominant, and in 1508 the Shah Ismail began to govern the region under the Safavid dynasty (Sümer, 1959).

After the battle of Chaldiran 1514, Kirkuk was bound to the Ottoman lands by Biyıklı Mehmet Pasha in 1516 (Pitcher, 1972). Between the 17th and the middle 18th centuries, there were a lot of contentions in the region between the Ottomans and Iran. Over the peace treaty between the Ottomans and Iran in 1746 (Uzunçarşll, 1973) Kirkuk remained on the Ottoman teretory until the British occupation 1918 of Iraq.

\section{The Development of City Structure}

It can be said that Kirkuk during the history was only the area of fortified city (Kirkuk Citadel), and it saved for a long time this identity. It's clear that the hedges lost their importance in the area during the fifteenth century and the settlements began to spread out of hedges. But in Kirkuk situation the settlement outside of the Citadel began in later periods, that is because of the absence of the politic settlement and the fact that the region being a field for long-lasting discords between the Ottomans' and the Iranians, these reasons caused the late settlement after the late of eighteenth (except some small areas) (see Figure 5) (Saatçi, 2003).

The city can be distributed in three parts according to the composing structure:

1- The citadel and the area beneath it.

2- The bisecting of the "Korya" in the other part of "khasa" river.

3- "Tiseen" area which was an independent village south Korya District, then it merged with the bisecting of Korya. 
Figure 5. Kirkuk city devolepment, the darker places represents the older parts of the city (Saatçi, 2003).

Figure 6. Western silhouette of the citadel (Anonymous, 2016)

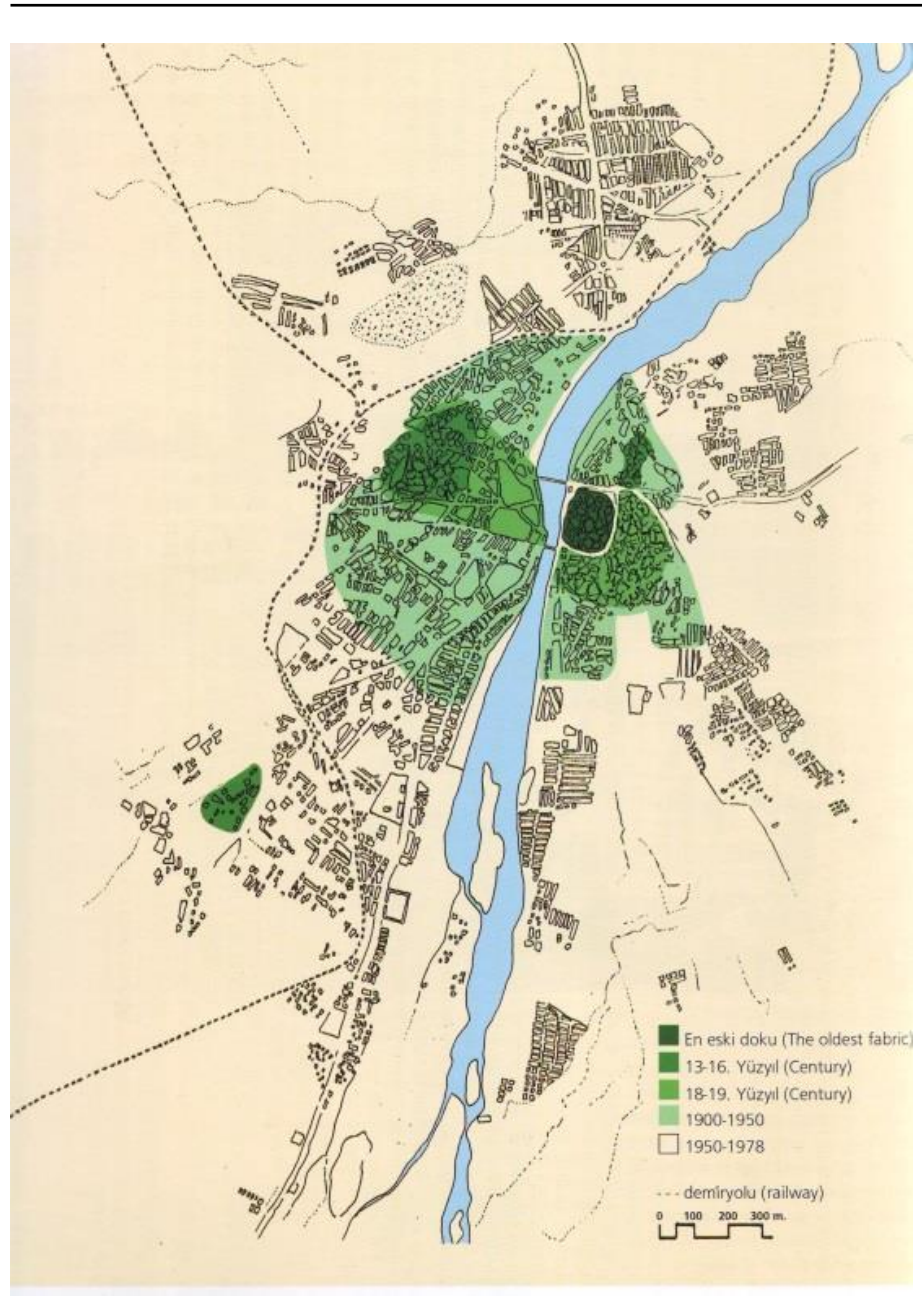

\section{KIRKUK CITADEL CHARACTERISTICS}

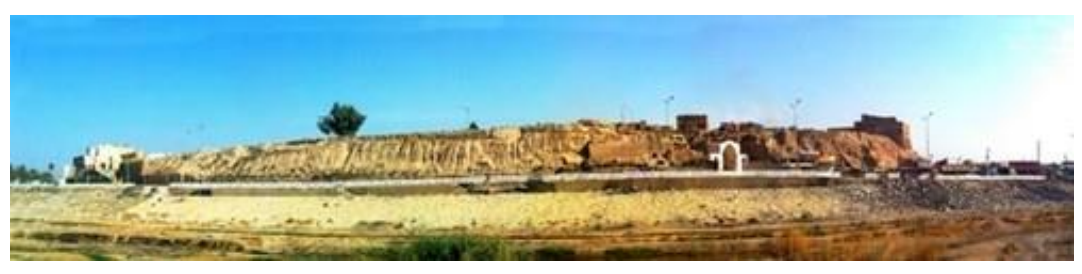

The idea of the citadel started with the need of protection from enemies aggressions, therefore it is surrounded by huge hedgeds. For Kirkuk citadel the hedgeds not remained in the scene today, the silhouette of the citadel is consisted of residential buildings, although the two northeren corners of rectangular fortress was excavated by the Antiquities and Heritage Department in Kirkuk, which were built with tauf. The other parts of the fortress may be remained under the foundation of houses that built across the borders of the citadel forming the new outline elevation of it. The invention of gunpowder made the traditional wall of a fortress useless especialy during the 15th century, so during that time the wall of the citadel neglected, and rich people started to build there houses above the old wall benefitting from the great view they will have at there. So the citadel become to seem more like a 
residential area over a tell, than a fortress with defensive wall. Kirkuk citadel had four gates (see figure 7), only one of them is remained, "Top Kapı" gate, which was constructed in 1882. The construction of the gate, of which a plan and an elevation drawing (see figure 7), was completed in the same year ( Saatçi, 2003, Archive of Prime Ministriy of Turkey).
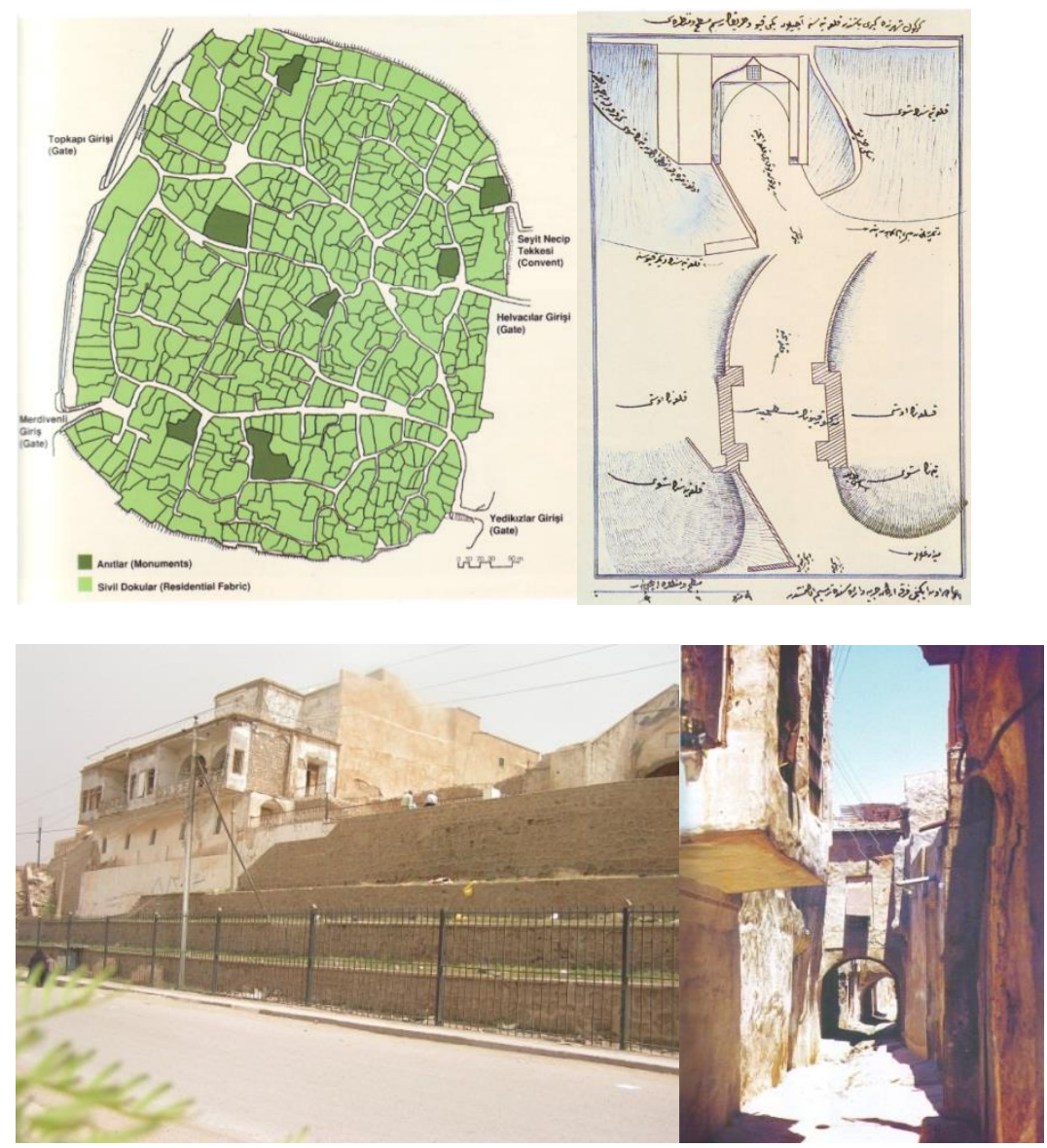

The citadel is allocated alongside the seasonal river Khasa $\mathrm{Su}$ from the West side, this river devides the city into two parts, Eski Yaka and Korya. The urban fabric of the citadel used to be consisting of narrow and organic alleys, and cul de sacs which sometimes covered with pointed arch vaults. This vaults called "Tak" which is considered a passage between two homes facing each other in the alley, where both homes often owned by the same person. These "Tak"s will provide a perfect shade for the pedesterians during the hot summer days and rainy winter season. Somtimes when different direction alleys intersect they form an open space which called "Meydan" which service as people gothering and meeting area, it also can be as open market fort he residence of the citadel. The most of the built area in the citadel were residential areas (more than 650 houses) interspersed with religious, administrative and monumental buildings. The house of Kirkuk contain a combination of architectural charecteristics between the Turkish and Iraqi heritage with special and unique charecter
Figure 7. from the left plan of the old urban fabric of the citadel. From the right plan and elevation of the Top Kapi (Saatçi, 2003).

Figure 8. from the left North western side of the Citadel. From the rıght an alley with "Taq" (Saatçi, 2003). 
which is the "Büyüg $E v$ " which can be seen in the plan of almost all the houses in Kirkuk and surrounded Turcoman cities and villages. It represents a functional combination of living room, bedroom and storage. These are briefly illustrated in the remarkable book of Prof. Suphi Saatchi (Saatçi and Uluengin, 2007).

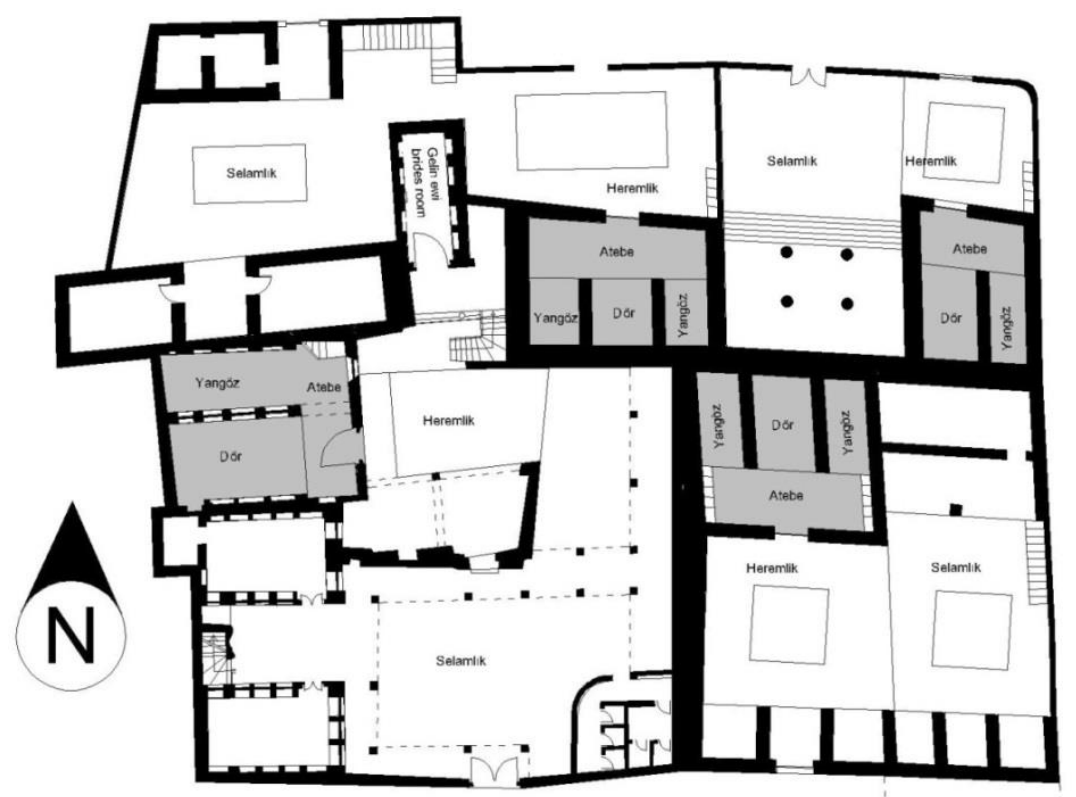

Figure 9. Four preserved houses in the Citadel, the shaded areas represent the "Büyüg Ev".

Figure 10. First image google arth record in 2010 and second one is arial foto of area before demolishing.

During the Nineties' within the Baath regime party the main goal of the authorities in Kirkuk that time was to erase the Turcoman identity of the City and Arabize it. Therefore the architectural monuments and the old districts were targeted, the citadel itself included (Mardan, 2004). In 1997 in the purpose of restoring the citadel the residents were taken out from their homes, bulldozers demolished every urban fabric in the citadel, from more than 650 houses only fewer than 50 had remained! The citadel from inside turned into semi vacant area with single monuments and houses stripped from their normal urban fabric.

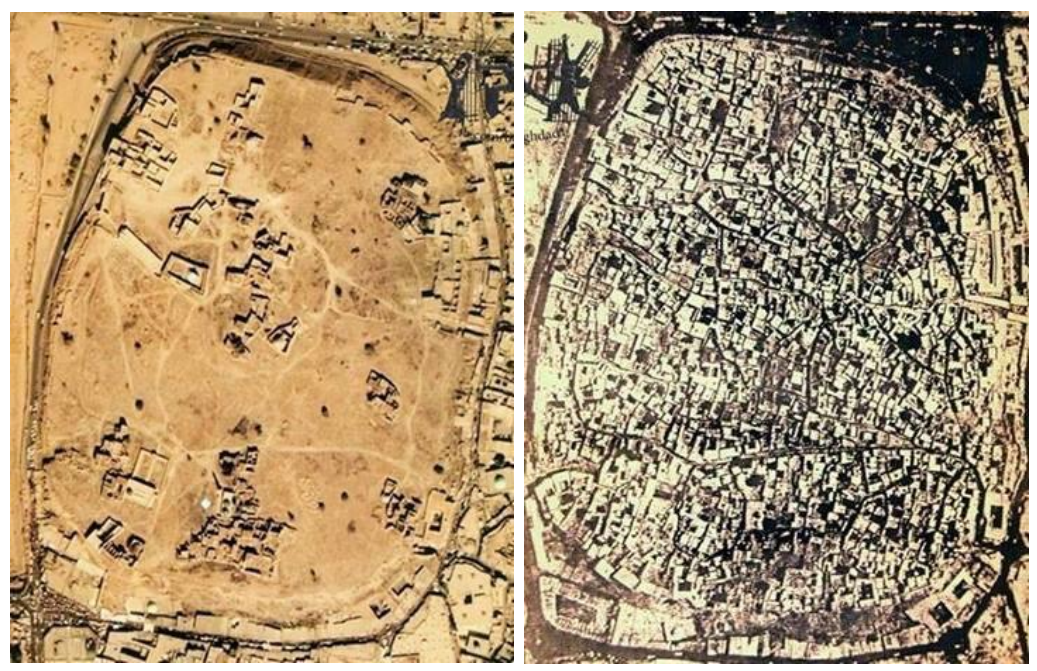




\section{METHOD AND NEW APPROUCH FOR KIRKUK CITADEL}

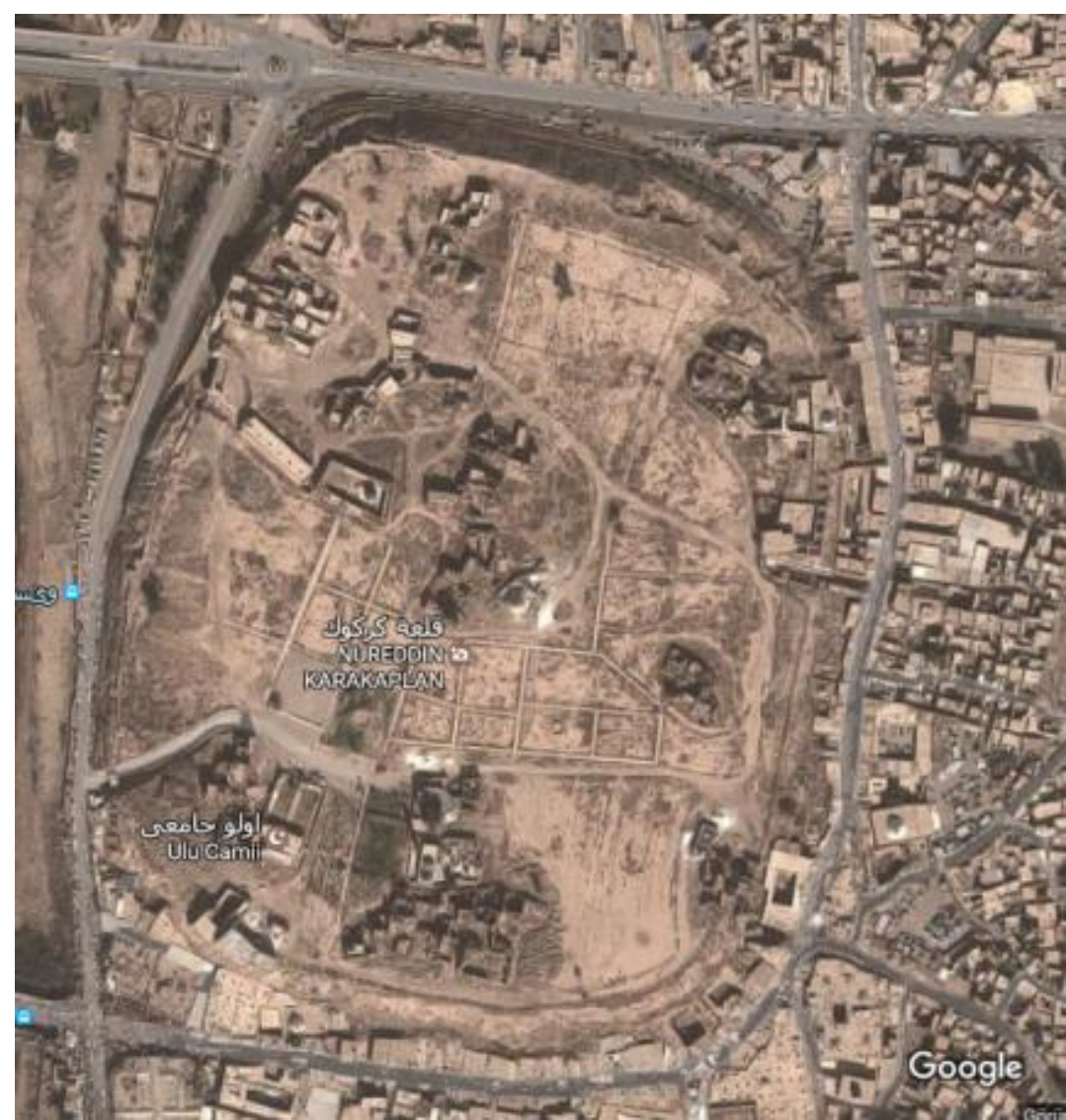

Unless passing by its side, Kirkuk Citadel nowadays seems like totally separated from the city. It's not clearly linked to the city. There was no vital activity created within it, nor movement axes between the city center and the citadel. It's noted that the growth of the city of Kirkuk came mostly in the other side of the river "Korya" in both directions away from the citadel (Figure 5). The Citadel still sadly stands without a proper interest in re-qualifying and making it one of the landmarks that can be benefited from in tourism and other sectors, besides linking it with the city and its urban activity.

In order to give new functions to Kirkuk Citadel and to the remaining buildings in it, the first step must be to determine the reasons for its reuse. Throughout history, functional improvements or emerging new requirements have left the most of citadel buildings' against functional obsolescence. As well as historical and cultural reasons, this relates to environmental and economic factors. Environmental changes may require reconsideration of the building. For example residences located in commercial areas in Kirkuk, may have to change their function, like the remaining of "Khanaka" house in the opposite side of the Citadel, which was within a residential area, it's now surrounded by crowded commercial buildings even some of these buildings
Figure 11. Kirkuk Citadel exposed to vandalism during Saddam regime, before and after September, 1997 (Matti, 2013). 
are existed within its territory. The environmental alteration from residential to commercial use led the original house being left for decay. The next step is to specify the design qualities that can be given by the buildings within the Citadel. The spatial form of construction is directly related to the new function which it can provide, and is perhaps the most important factor. For example, if a Khan reused as a cinema, it may never work or it will make a great loss to the architectural and historical identity of the building. The volumetric dimensions of the building are a factor for choosing a new function, requires the analysis of the main unit of the given function, if the building is a hotel the main unit is a hotel bedroom, if it is a primary school it's a classroom etc. A monument may appear to be a hotel by being divided horizontally and vertically several times, but in this time the historical and architectural value of the building will disappear. Another factor is the functional curriculum of the building; the new function must be compatible with the natural circulation of the building. Finally, the location of the building is an important factor. For instant, the inner-city Khans of the eastern and southern sides of the Kirkuk Citadel (see figure 13) through the city's crowded trading center can be hotels according to the three factors above, but due to its important commercial position within the city, it is more accurate in terms of economy to separate those structures for the commercial functions (Altınoluk, 1998).

Figure 12. the commercial land use downside and around the Citadel (MGArchitects, 2013) edited.

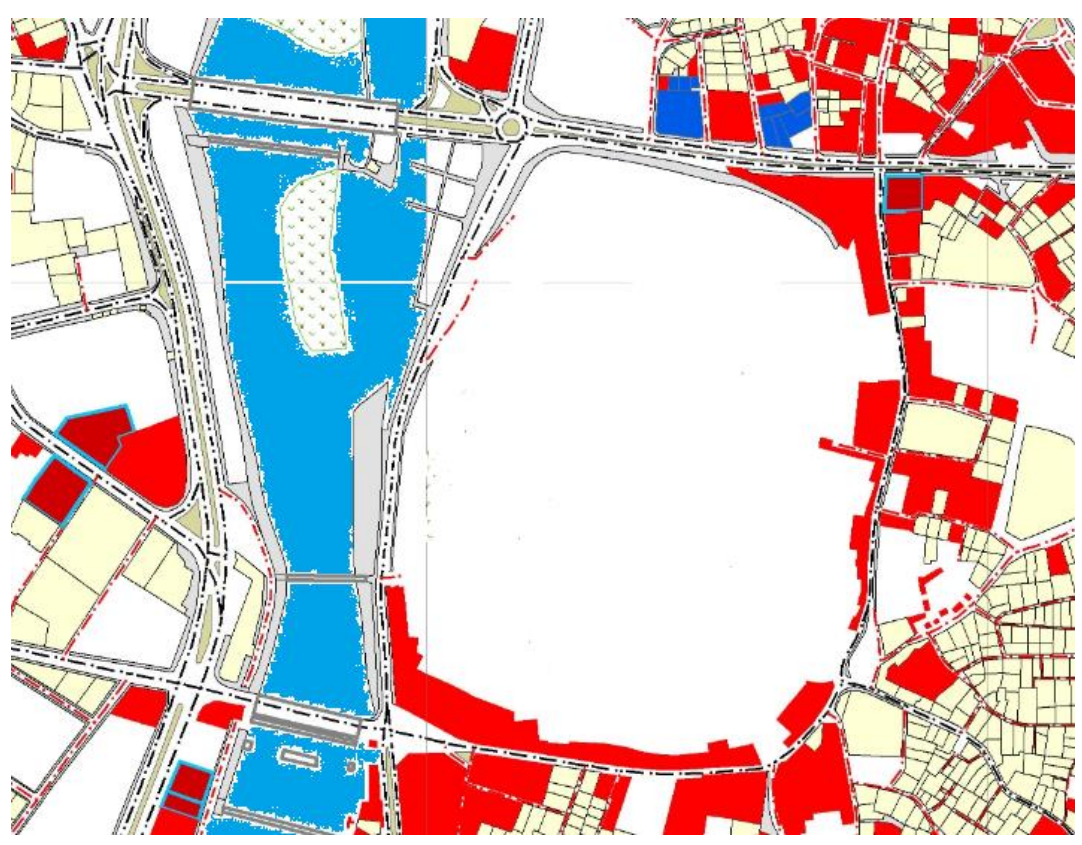

In order to get a clear idea of the new approach for the Citadel, a part from the Citadel selected to apply the method above. The North-Western part of the Citadel (Maydan district) will be a good selection, because it contains most of preserved and remained houses (nearly 20 houses). The orange color units in (figure 14) 
represent the preserved house, light green refers to Hassan Pakiz Mosque, and dark green unit refers to the tomb of Seljuk princess "Baghda Ay Hatun" which is known as the "Gok Kunbet" between the people and finally the red unit represents the old bazar "Kilchiler Bazar". The other houses and building are not remained during the 1997 demolishing's as mentioned above. The remaining and preserved houses and monuments are in very bad conditions, some of the houses are only ruins, lost many of its architectural characters, and the restoration of them is needed urgently. Neither documentation nor data were taken for the Citadel before the demolition took place, only a general plan which contains simply the building units and the alleys formed between them (see figure 14). So the restoration of the ruined houses must depend on architectural character of preserved and documented houses of traditional Kirkuk houses. In the bellow figure 13, the lost items of the parapet, handrail and other ornaments are regained depending on the traces existed in the site and the similar examples of the traditional Kirkuk houses, not forgetting the eye witnesses from the old people which were used to live in the Citadel.

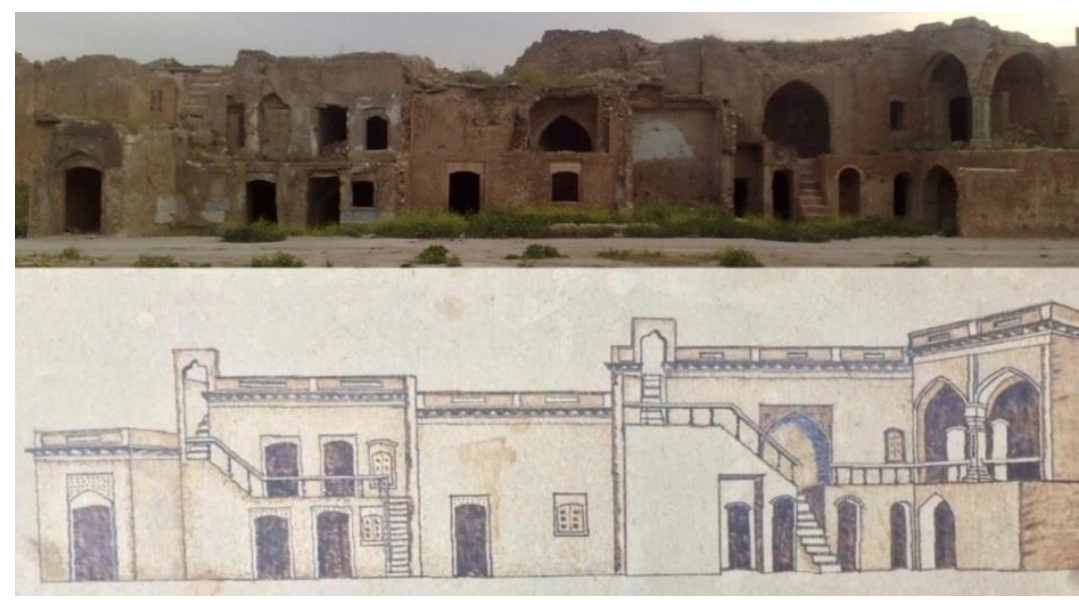

After projecting the outline of the demolished houses and the vanished alleys in the current situation plan of "Maydan" district (see figure 14), it's clear how the old fabric and the sense of place disappeared, only single buildings almost like the Seljuk outside cities' Kervansarays, the organic structure of the old district nearly or maybe completely disappeared.
Figure 13. The restoration of four neighboring houses in Maydan district, elevation (the author). 
Figure 14. from left Citadel General Plan (Archological directorate) edited. From right the site plan of "Maydan" district (the author).

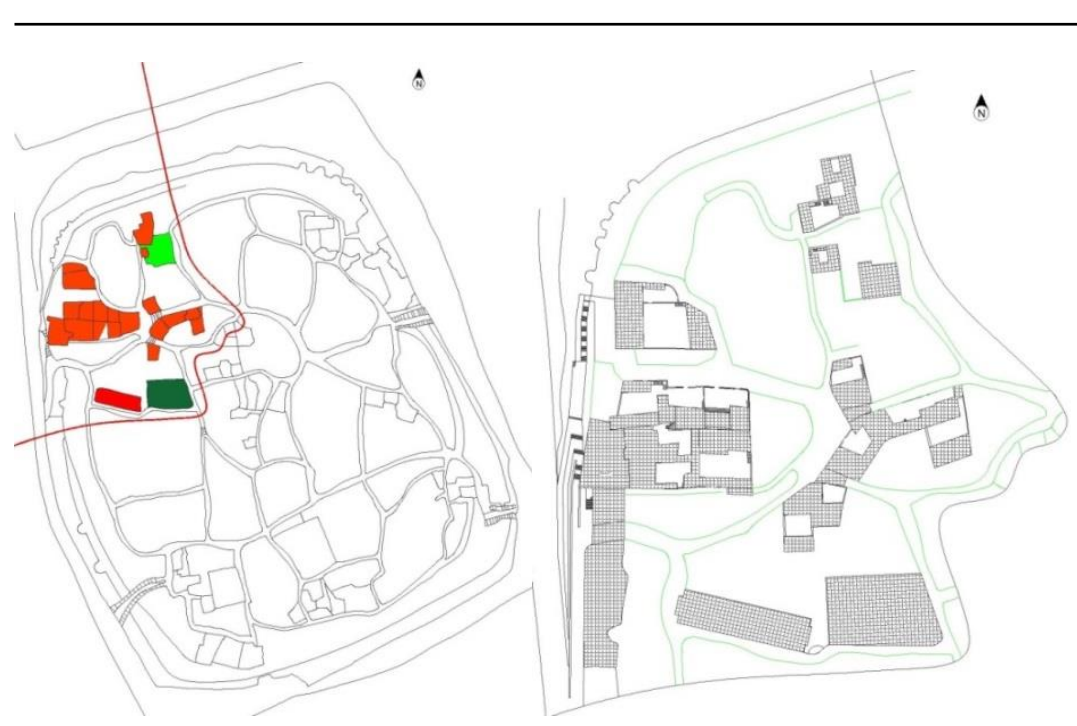

In order to regain the original sense of enclosure and the organic structure of the urban fabric of the Citadel, adding new structure to the scene will be inevitable. The new structured buildings will follow the original characteristics of Kirkuk Citadel which explained briefly above in the Kirkuk Citadel Characteristics section. The new structure will follow the path of the alleys that is documented and projected on the general plan, as well as the allocation of the building units around the alleys (see figure 15). The plan characteristics of the "Buyuk Ev", the courtyard and its entrance "Taq Alti" and other characteristics will be the guideline for the designing of the new plans. Building materials will be stone and the local traditional gypsum which is called "Nura". These new additions will host for as much as possible the services' parts of the new functions to minimize the possible damages on the original buildings from reusing it. Maydan district is the farthest part of the Citadel from the commercial area and it has its own gate which called "Top Kapi", so these factors make it the best place to host cultural, recreational and touristic functions. New functions like ethnic museums, small library with reading areas, educational hall (Hassan Pakiz Mosque), recreational house for kids, small boutique hotels and a gallery (Kilchiler Bazar) will be the proposed functions for the original buildings. Multipurpose hall, recreational area, outdoor, small café, museum administration and services, and finally a traditional institution will be the functions of the new structured buildings. The new functions were created to arise awareness of the importance of heritage between kids and the younger generation and to provide institutions that teach the younger generations the traditional craftsmanship and to protect it from loss. These functions will also bring people from the west side of the Citadel which used to be a very low density area. The other parts of the Citadel are recommended mostly for commercial functions. 


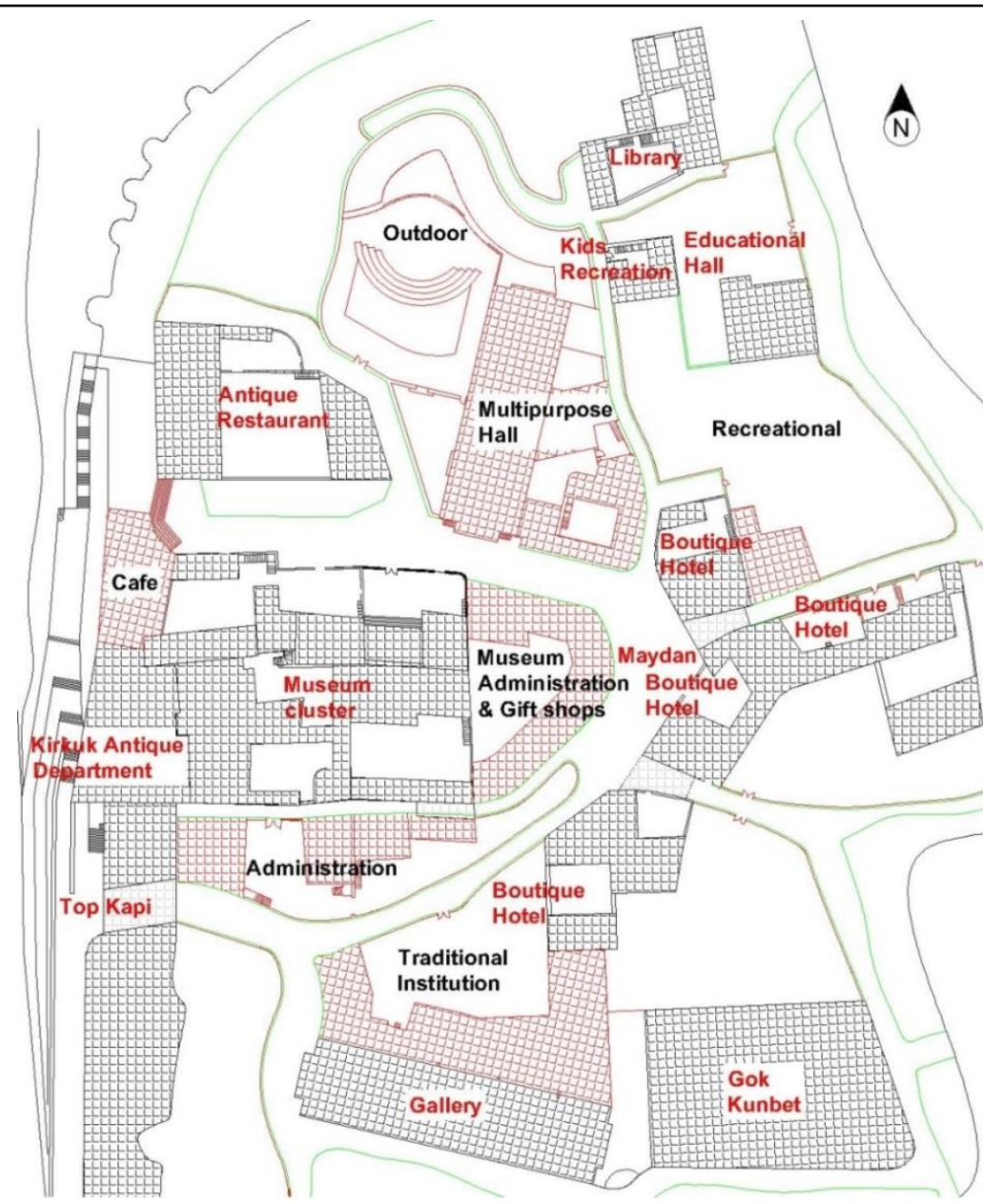

Taking into account the variability of requirements, the action must be rigorous in historical constructions, mistakes should not be experienced. Every decision should not be gainful, especially in the context of monumental structures.

\section{CONCLUSIONS}

Old buildings become unsuitable for their designed requirements, as development in technology, politics and economics moves faster than the built environment; adaptive reuse comes in as a sustainable option for the reclamation of sites. Citadels are considered the historical monuments and landmarks that the cities are known by, as in Aleppo, Kirkuk and Erbil Citadels. The Citadels in these kinds of cities hedged the old city during the ancient times and until the late Middle Ages, these cities grew form inside the citadels in different directions around the citadels. The shape of citadel, the nature of the land use within it and the axes came out from it determines the city's growth. A suitable approach for Kirkuk Citadel must link it with surrounding neighbors and the city as a whole, by pedestrian axes and new functions that will attract the society and tourists to the Citadel.
Figure 15. New functions for the original and new added buildings (the author). 
The absence of the historical urban fabric of Citadel may lead to persistent need for reconstruction, in order to regain the original sense of enclosure within the neighborhood of the Citadel. Due to the small sizes of spaces within the original buildings of Citadel it can't satisfy a cinema activity for example, but it can be boutique hotels, small shops or maybe special museums, some Mosques can reuse as a schools with others maintain its same religious functions. Activities like cinema, outdoor or indoor stages, services etc. can be located within the new constructions.

\section{ACKNOWLEDGEMENT}

This article is prepared by expanding the proceeding presented in the ICONARCH III, held at Selçuk University in May 11th-13th, 2017.

\section{REFERENCES}

Aga Khan foundation official web page., (2014), http://www.akdn.org/architecture/project/manouchehr i-house, web.

Al- Samarrai, A. M. كركوك مدينة الذهب الأسود, مجلة الفيصل (1988), yll:12, sayı:134, p. 11-19.

Ali Haider Al-Jameel, Dara Talaat Al-Yaqoobi, Wafaa Anwar Sulaiman, (2015). Spatial configuration of Erbil Citadel: It's potentials for adaptive re-use, Proceedings of the 10th International Space Syntax Symposium.

Al-Jameel, A. H., Al-Yaqoobi, D.T., Sulaiman, W. A. (2015) Spatial configuration of Erbil Citadel: It's potentials for adaptive re-use, Proceedings of the 10th International Space Syntax Symposium.

Altınoluk, Ü., (1998) Binaların Yeniden Kullanımı, T.C. Kültür Bakanlığı, birinci yayım, Güzel Sanatlar Matbaası, YEM Yayın, İstanbul.

Annoymous, (2016), Kirkuk Citadel Panorama, (2016) http://mapio.net/pic/p-13537656/.

Ayalon, D., (1999) Eunuchs, Caliphs and Sultans: A Study in Power Relationships, Hebrew University Magnes Press.

Bakır, T., Sefer, F., دار الطباعة والنشر, المرشد الى مواطن الأثار (1965) Bağdat.

National Archives, Republic of Turkey Prime Ministry , "Sicilli Ahval Defterleri, A. MKT. UM., 1688/65".

Berry W., (2016) Personal quote. https://prezi.com/blydyjazqc5z/if-you-dont-knowwhere-youre-from-youll-have-a-hard-tim (access date:10.11.2017).

Bixler, R. D., M. F. Floyd, and W. E. Hammitt. (2002) Environmental socialization: Quantitative tests of the childhood play hypothesis, Environment and Behavior, p.11. 
Brooker, G. \& Stone, S., (2004) Re-readings. Interior architecture and the design principles of remodelling existing buildings. RIBA Enterprises: London.

Cantacuzino, S., (1989) Re/Architecture: Old Buildings/New Uses. Thames and Hudson: London.

Chipperfield, D., (1997) Recent Work, p.131 Barcelona.

Cramer, J. \& Breitling, S., (2007) Architecture in existing fabric. Birkhäuser, Berlin.

Langston CA, (2008) The Sustainability Implications of Building Adaptive Reuse, Mirvac School of Sustainable Development, Bond University, Brisbane, Australia.

East, W. G., Oskar Hermann Khristian Spate Methuen, (1961) The Changing Map of Asia: A Political Geography, London.

Encyclopedia Britannica Online, (2010) "Art conservation and restoration". Encyclopedia Britannica, 2010. Web.

UNESCO (2010), Erbil Citadel World Heritage Centre, http://whc.unesco.org/en/list/1437 (access date: 13.12.2017)

Giebeler, G., Definitions, (2009) Refurbishment Manual: Maintenance, Conversions, Extensions, ed. J. Liese, pp. 1015, Birkenhauser: Basel, Boston \& Berlin.

Griffith, R. (2010) 'Listed building control? A critique of historic building administration', Cultural Trends, p.192.

Highfield, D., (1987) The rehabilitation and re-use of old buildings, Spon Press (Taylor and Francis): London \& New York. https://www.goodreads.com/quotes/102492-if-youdon-t-know-where-you-re-from-you-ll-have-a [Access Date, 13.12.2016]

Edwards; I E S, Bury, J B, Cook, S A; Adcock, S A; Charlesworth, M.P., (1970) The Cambridge ancient history. 3: The Assyrian Empire.

Jäger, F., (2010) Old \& New. design Manual for Revitalizing Existing Buildings. Birkhäuser: Basel.

Jawad, M., مختصر نأريخ الترك في العراق , مجلة الدليل (1947) yll:1, sayı:5, Necef, s. 279-284.

Jessen, J. \& Schneider, J., (2003) Conversions - the new normal, Building in Existing Fabric -Refurbishment Extensions New Design, pp. 11 - 21, Birkhäuser: Basel.

Johnson, A. (1996) "Rehabilitation and Re-use of Existing Buildings", in Mills E D. Building Maintenance and Preservation: A guide to design and management (second edition), 209-230. Oxford: Architectural Press.

Latham, D. (2000) Creative Reuse of Buildings, Donhead, Shaftesbury, Volume 1, and MASON op cit.

Latham, D., (2000) Creative re-use of buildings vol. 1\&2, Donhead: Shaftesbury.

Lindberg, J. and Goldberg, G. (2013) Partnership for Building Reuse, learning from Los Angeles. Posted on October $10^{\text {th }}$.

Machado, R., (1976) Old buildings as palimpsest. Towards a theory of remodeling, Progressive Architecture, 11, pp. 4649.

Manouchehri House, (2016) http://www.manouchehrihouse.com/en/hotel

Mardan, N., اغتيال قلعة كركوك, نصرت مردان (2004) , Kirkuk. 
Merriam Webster Dictionary, 2016. web.

Orbasli, A. (2009) Re-using existing buildings towards sustainable regeneration, School of Architecture: Place Culture \& Identity Group working paper, Oxford Brook University.

Pitcher, D.E., (1972) An Historical Geography of the Ottoman Empire, E.j, Brill, Leiden.

Plevoets, B, \& Van Cleempoel, K., (2011) Adaptive reuse as a strategy towards conservation of cultural heritage, PHL University College \& Hasselt University, Belgium.

Pollard, E. (2015) Worlds Together Worlds Apart. 500 Fifth Ave New York, NY: W.W. pp. 128-130. Norton Company Inc.

Powell, K,. 1999. Architecture Reborn: Converting Old Buildings for New Uses; Michigan Üniversitesi, Laurence King.

Powell, K., (1999) Architecture Reborn, Laurence king publishing, p19, 168. London.

Robert, P., (1989) Adaptations. New Uses for Old Buildings. Editions du Moniteur: Paris.

Rydon, K., (2014) from "Making Sense of a Sense of Place" by Cynthia Neely, The Writer's Chronicle (vol. 46, no. 5.

Saatçi, S., Uluengin, M. B. (2007). The Urban Fabric and Traditional Houses of Kirkuk. Kerkük Vakfi.

Saatçi, S., (2003) Kerkuk Evleri, Klasik, Istanbul.

Sicker, M., (2000) The Pre-Islamic Middle East, Greenwood Publishing Group.

Snyder, G. H. (2005) Sustainability through Adaptive Reuse: The Conversion of Industrial Building. Master University of Cincinnati.

Sourdel, D. (2010) "Irbil", in Bearman, P.; Bianquis, Th.; Bosworth. C.E.; van Donzel, E.; Heinrichs, W.P., Encyclopaedia of Islam (second ed.), Brill Online.

Sümer, F., (1959) Irak Türklerinin Tarihine Kısa Bir Bakış, Türk Yurdu, 49/255.

Turan, O., (1965) Selçuklular tarihi ve Türk İslam medeniyeti, Ankara üniversitesi basımevi, Ankara.

UNEP, (2009) Buildings and Climate Change: Summary for Decision-Makers. ed.: UNEP publications.

Wallsgrove, J. (2008) The justice estate's energy use, Context, No $103,19-20$.

Weeks, K.A. and Grimmer, A. E. (1995) Preserving, Rehabilitating, Restoring \& Reconstructing Historic Buildings, U.S. Department of the Interior, National Park Service, Cultural Resource Stewardship and Partnerships, Heritage Preservation Services, p: 25,68,123,170. Washington, D.C.

William, M., (1922) The Caliphate, Its Rise, Decline and Fall: Bölüm LXVII, Al-Mo'tasim and al-Wathik. 


\section{Resume}

Mustafa Korumaz, obtained his Bachelor Degree from Selçuk University Department of Architecture in Konya (Turkey) in 1999. He got his Master Degree with title Examination of new additions to historical buildings: examples from Istanbul in Selçuk University Natural and Applied Science Institution in 2003. He got his PhD degree with title Evaluation of Façadism Applications on Historic Buildings in Context of Conservation in Turkey in Selçuk University Natural and Applied Science Institution in 2011. He workd in Italy, for his post-doctoral study about the items New Additions on Historical Building and Environment and Façadism under the supervision of Prof. Maurizio De Vita and also, Laser Scanning Technologies for analyzing of historic structures with Prof. Gianni Bertoli in Florence University. He has taught in Selçuk University since 1999. He generally working on restoration and adaptation of historic buildings, new design methodologies in historic buildings and environments, documentation of historic buildings. 